\title{
COMPARES mRNA AND ADENOVIRUS-BASED SARS-CoV-2 VACCINES
}

\author{
HISA FAADHILAH ${ }^{1}$, KARINA O. WISEVA ${ }^{1}$, FRIDA WIDYASTUTI ${ }^{1}$, NASRUL WATHONI ${ }^{2}$
}

${ }^{1}$ Bachelor Program in Pharmacy, Faculty of Pharmacy, Universitas Padjadjaran, Sumedang 45363, Indonesia, ${ }^{2}$ Department of Pharmacy and Pharmaceutical Technology, Faculty of Pharmacy, Universitas Padjadjaran, Sumedang 45363, Indonesia

Email: nasrul@unpad.ac.id

Received: 05 Aug 2021, Revised and Accepted: 15 Oct 2021

\begin{abstract}
This review is aimed at looking at the Covid-19 vaccine, formula and comparison of mRNA (Moderna and Pfizer) and adenovirus vector (AstraZeneca) vaccines that have been circulating in terms of administration, effectiveness, safety, side effects, contraindications, and in terms of price. This review was conducted by taking some literature from a database that focuses on the Covid vaccine, the development of the Covid vaccine, the Moderna vaccine, the Pfizer vaccine, and the AstraZeneca vaccine. Three vaccines, 2 were mRNA-based vaccines (Moderna and Pfizer) and 1, namely AstraZeneca, was based on adenovirus vectors. The results obtained are from international journals with the keyword comparison of mRNA vaccine and adenovirus vector, then the results show that the comparison can be seen through the method carried out. Some vaccines have their own advantages and disadvantages. When viewed from several aspects, such as administration which has different doses. Then seen from the effectiveness of the three vaccines have a sufficient value because they are above $80 \%$. For safety, it has passed clinical trials in humans, but there are still shortcomings in each vaccine of course. Vaccines derived from mRNA (Moderna) are the most expensive vaccines because of the highest safety.
\end{abstract}

Keywords: Vaccine, Covid-19, Effectiveness vaccine

(C) 2021 The Authors. Published by Innovare AcademicSciences Pvt Ltd. This is an open access article under the CC BYlicense (https://creativecommons.org/licenses/by/4.0/) DOI: https://dx.doi.org/10.22159/ijap.2021.v13s4.43822 Journal homepage: https://innovareacademics.in/journals/index.php/ijap

\section{INTRODUCTION}

The Severe Acute Respiratory Syndrome Coronavirus (SARS-CoV), H5N1 influenza A, H1N1 2009 and Middle East Respiratory Syndrome Coronavirus (MErS-CoV) cause Acute Lung Injury (ALI) and Acute Respiratory Distress Syndrome (ARDS) which leads to pulmonary failure and result in fatality. The viruses mentioned earlier only infect animals, until there was a severe acute respiratory syndrome (SARS) outbreak caused by SARS-CoV 2002 in Guangdong, China [1]. In December 2019, a pneumonia outbreak was discovered in the Wuhan area, China, which spread rapidly throughout the world as a pandemic. This epidemic is known as Covid-19 (Corona Virus Disease 2019) which belongs to the type of SARS-CoV-2 contagious and can infect humans quickly with various symptoms [2]. Covid-19 is known to spread through contact/airborne droplets such as coughing or sneezing. In young people, usually, the symptoms that appear are only mild depending on the immune system [3]. Symptoms will appear about 2-14 d after the virus infection and $5.1 \mathrm{~d}$ in median. Covid-19 is thought to react with the receptor for the angiotensin-converting enzyme 2 in humans with higher transmission rate than that of SARS-CoV. The possible reason is that the occurrence of gene recombination of the $S$ protein in the RBD region of SARS-CoV-2 may affect the transmission ability [4].

The Covid-19 virus originated from the presence of SARS-CoV-2, occurred by way of contamination and spread quickly to all countries, especially through interactions that interact or infect people by dripping saliva from the nose when a sick person coughs and sneezes. The first infection of the coronavirus in the world was in 1960. Coronaviruses are divided into four generative types, namely $\alpha, \beta, \gamma$, and $\delta$. Coronaviruses of $\alpha$ and $\beta$ generally typically contaminate mammals and humans while the type of $\gamma$ and $\delta$ genera mainly infect birds. This coronavirus has a size of about $65-125 \mathrm{~nm}$ in diameter and consists of single-stranded RNA as nucleate material, and has a size range of $26-32$ kbs in length [4]. Corona virus has a shape like a ball with sharp edges on the surface called spikes. The viral membrane contains 4 components, including spike $(\mathrm{S})$, envelope (E), membrane $(\mathrm{M})$, and nucleocapsid protein $(\mathrm{N})$ [5]. Severe acute respiratory syndrome coronavirus 2 (SARS-CoV-2) is the virus causing coronavirus disease 2019 (Covid-19), uses the angiotensin-converting enzyme 2 (ACE2) as a cell receptor to invade human cells. Thus, ACE2 is the key to understanding the mechanism of SARS-VoV 2 infection. In research using ACE2, it turns out that the coding for ACE2 shows that this transcript is co-expressed in various cell types and according to several studies, SARS-CoV-2 can be seen in several organs, including the lungs, liver, heart, kidneys and brain. So SARS-CoV-2 may infect other tissues aside from the lungs and infect persons with different sexes, ages and races equally [6]. When a person is exposed to coronavirus, the virus can spread to various body tissues. To reduce the spread of transmission from this virus, several trials of the drug are being tested to treat the coronavirus such as remdesivir, chloroquine, hydroxychloroquine, losartan, favipiravir, and many others [7]. However, because this strategy cannot relieve and cure patients, the next step is planning, namely the development of a vaccine to induce the virus and form a body's defense system against this virus.

For the development of vaccines against SARS-CoV2, the spike protein i.e. protein $\mathrm{S}$ has been the main target, based on the elicitation of virusneutralizing antibodies. After clinical examination of vaccines used against MERS-CoV, SARS-CoV and other coronavirus vaccines, it was found that there were causes related to their toxicity regarding the application and application of vaccines based on spike proteins including inflammatory and immunopathological effects, PEI and ADDE [8]. During the pandemic, the World Health Organization (WHO) organized a group of specialists dedicated to immunization against Covid-19. Each vaccine in its development requires different logistics, management, and administration training. For example, the PfizerBioNtech vaccine requires a high-tech cold chain for transportation [9]. After knowing the definition, conditions, and forms of the coronavirus, later in this article, we will discuss further about the Covid-19 vaccine, which is well known to the public, namely the Moderna vaccine and the Pfizer vaccine from the United States. Then there is the AstraZeneca vaccine which comes from England and is produced by the University of Oxford. All three vaccines have further advantages and disadvantages. In the discussion, we use the method by looking at the comparison of several aspects.

\section{METHODS}

This literature review is based on valid journal sources obtained from Scopus, Google Scholar, and Pubmed using different keywords, including "Covid vaccine", "covid vaccine development", "Moderna vaccine", "Pfizer vaccine". The reference journals that we use are in the range of 2012-2021. We excluded opinions, reviews, mechanisms, and pharmacological properties. The database is limited to obtain specific topics, namely comparing Moderna, Pfizer, and AstraZeneca vaccines. 


\section{RESULTS}

During Covid 19 pandemic, several scientists are developing the discovery and development of a Covid-19 vaccine that can fight the spread and the catastrophic effects of this disease. WHO has released a draft list of vaccines since 3 September 2020 [10]. Many efforts have been made to develop drugs and therapies for Covid-19, one of which is the development of vaccine candidates and the most widely developed vaccines are those that use the S-protein from SARS-CoV-2 [11]. The manufacture of vaccines requires a complex process and takes about 12-15 y [12]. The difference between vaccines and drugs is that vaccines are used for people whose symptoms have not yet appeared and to prevent the disease, while drugs are used when the person has been infected with covid and has symptoms of covid [13]. The vaccine will work by providing the immune system defense needed to recognize and form a defense against the microorganism itself, namely the Covid-19 virus [14]. Vaccines work as distinctive molecular markers known as antigens that are injected into the body from attenuated vaccines. These antigens can cause disease, but they can still activate the immune system, and the cells can form antibodies. If someone makes contact with a person who has the original pathogen, then that person already has antibodies formed from the immune system, which are given through the vaccine quickly because they have been sensitized by the vaccination [15]. Once a vaccine is available, the success of a vaccine program depends on the response of the patient to the public [16]. A safe and effective vaccine must be available immediately, where this pandemic has been detrimental in terms of social, economic, and health [17]. The ingredients used for vaccines have to be confirmed and their safety through clinical trials, then you can develop them [18]. With the rapid evolution of the Covid-19 vaccine, the role of the formulation requirements used will result in a vaccine with an optimal formulation [19]. Global immune deficiency is a risk factor for the efficacy of Covid-19 vaccines, especially in older people [20] who have several factors that affect the immune system. Factors that can cause immune deficiency include obesity, type 2 diabetes, metabolic syndrome, and immunemediated cancer [21]. The causes of some of these diseases can affect the administration of vaccines, including antigen recognition, decreased quantity of immune cells and their functions, increased levels and timing of components of humoral immune prolongation, decreased cellular response, and memory cell damage [7].

The safety of vaccines depends on the result of pre-clinical trials on animals and clinical trials on humans. Pre-clinical testing was carried out on mice or rabbits in vitro and in vivo. In phase I of clinical trials, the vaccine was tested or administered to a small group of healthy volunteers of about $10-100$ people. In this phase, it is seen whether the vaccine is safe or causes side effects. Then, it continued to phase II, where the vaccine was given to a larger group of subjects with certain conditions/disease $100-1000$ people and phase III where the vaccine was tested to $1000-100000$ people. Testing of this vaccine is carried out on various age groups, starting from children, adults, and the elderly [7]. The clinical significance of SARS-CoV-2 neutralizing antibody and binding antibody titers and their ability to predict safety needs to be confirmed. This is done as a guide in determining the dose before it is verified. Confirmation between important antibody titres and protection against Covid-19 is possible only in large clinical efficacy studies[19]. The production of this vaccine must contain an element of novelty and be adapted to current conditions. This flexibility will later facilitate the achievement of the latest covid vaccine technology, which is currently being developed based on nucleic acids (mRNA vaccines or other vector vaccines) [22]. If severe symptoms of inflammation are found or that can compromise the immune system, then the candidate vaccine being tested is not suitable for use or dissemination [23]. Evidence that the body can receive the Pfizer vaccine is evidenced by one large, randomized, double-blind, placebo-controlled Phase II/III clinical trial of a study conducted with $>43,000$ participants in the United States with an average age of $52 \mathrm{y}$, with a median of 2 mo ago showing that This Pfizer vaccine is 95\% effective [24].

The manufacture and development of vaccines has a high failure rate because of the uncertainty of the immune system's response to the antigen as well as from the organism's side. Vaccine candidates can provide an appropriate immune response but also give an adverse reaction, it can also happen the other way around. Vaccine discovery usually takes several years and costs a lot of money. Once found, development is carried out to achieve licensing. Following are the stages of development:

\section{Vaccine discovery}

2. Process development carried out to meet economic, consistent, and regulatory feasibility

3. Clinical development consisting of 3 phases to measure safety and effect

4. Assay development to assess suitability and ensure purity, stability, the potency of vaccines [25].

In the development of the manufacture of new vaccines, various methods are used, one of which is nanotechnology. Nanotechnology has been explored in search of vaccine designs [26]. The nanoparticles in the vaccine were constructed to display the receptor-binding domain (RBD) of SARS-CoV-2 along with multiple receptor-binding domains of the animal beta coronavirus [27]. These so-called mosaic nanoparticles are produced using SpyTag/SpyCatcher Technology for the conjugation of recombinant proteins [28]. More than 60 subunit vaccines against SARS-CoV2 have been developed, including RBD-trimer protein S, S1, recombinant protein S, protein $\mathrm{N}, \mathrm{M}$, and others. One of them is in phase III clinical trials, four are in phase II trials and seven are in phase I trials [29]. Development of a Covid-19 vaccine in 6 mo for each phase as shown by fig. 1 [7].

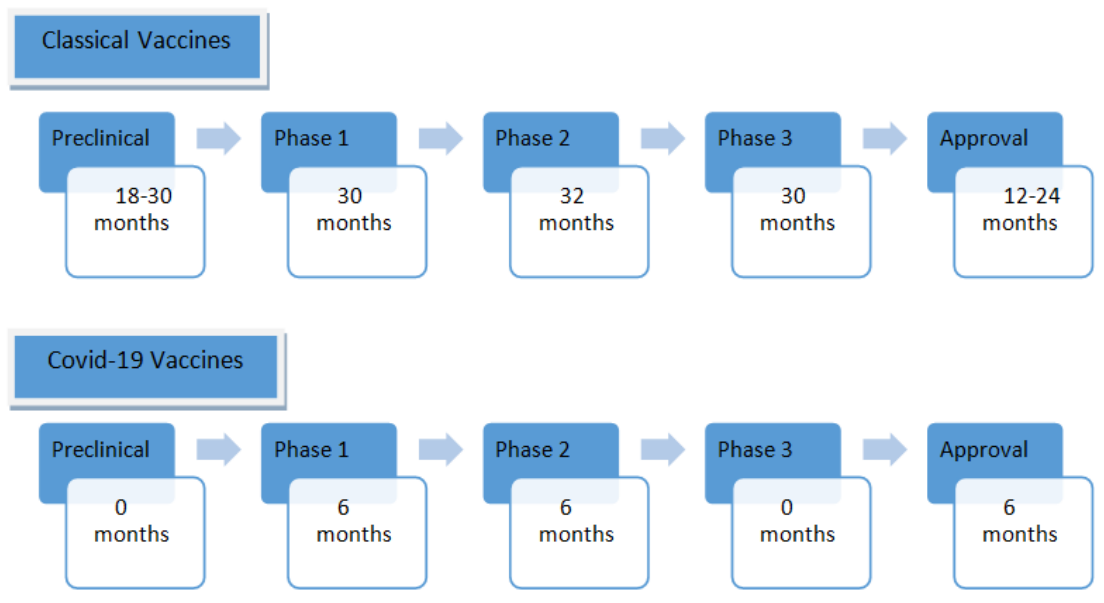

Fig. 1: Vaccine development timeline [7] 
Vaccines in the first phase are an exploratory phase involving basic laboratory bench research and computational modeling to identify natural or synthetic antigens that can be used as vaccine candidates that can help prevent or treat a disease [30]. The preclinical stage which will involve culturing cell or tissue culture systems and testing on test animals to assess the safety of the vaccine formulation and its immunogenicity or ability to provoke an immune response. Once safe, immunogenicity and efficacy are demonstrated in animals, then proceed to manufacture for human clinical trials that test safety and immunogenicity in small groups then large groups for 3 phases and so on until approval which testing can take up to $6 \mathrm{mo}$ [31].

\section{DISCUSSION}

The Covid-19 pandemic endangers the health and the world's economy [32]. Vaccines for Covid-19 began to be developed due to pandemic conditions with severe acute respiratory syndrome coronavirus 2 (SARS-CoV-2). Researches were carried out to develop prevention of the coronavirus to reach 31 vaccine candidates for clinical trials [33]. Moderna vaccines need only 2 mo from the release of the viral genome sequence to develop mRNA1273 for clinical trials. In July 2020, the company that developed the
Moderna vaccine announced its safety and protective immune response after passing phase I trials [34]. Then for the vaccine, Pfizer/BioNTech has announced safety and immunogenicity data BNT162b2 has passed phase I testing and is progressing to phase 2 trials. In November, Moderna and Pfizer announced excellent results in their trials and the efficacy of both vaccines [35]. The efficacy results obtained are $94.1 \%$ [36] for the Moderna vaccine and 95\% [17] for the Pfizer vaccine and passed phase II safety testing. In addition, moderna vaccines show $100 \%$ efficacy against severe Covid-19 some vaccine candidates include recombinant proteins, DNA vaccines, attenuated/live viruses, and mRNA-based vaccines [37]. Of the many vaccines, including the Covid-19 vaccine developed by Moderna, Pfizer, and AstraZeneca. The vaccine developed by Moderna and Pfizer is an mRNA-based vaccine that uses lipid nanoparticles; this vaccine has been granted EUA (emergency use of authority) by the FDA. The Covid-19 vaccine developed by AstraZeneca uses an adenovirus vector [38]. Then there are three vaccines that can be said to have a fairly expensive price; the following table compares the composition of the three vaccines.

Table 1: Composition of vaccine mRNA and adenovirus vector

\begin{tabular}{|c|c|c|c|}
\hline \multirow{2}{*}{$\begin{array}{l}\text { Vaccine } \\
\text { mRNA Vaccine }\end{array}$} & \multirow[b]{2}{*}{$\begin{array}{l}\text { mRNA-1273 } \\
\text { (Moderna) }\end{array}$} & \multicolumn{2}{|l|}{ Composition } \\
\hline & & $\begin{array}{l}\text { mRNA encoding the } \\
\text { prefusion-stabilized spike } \\
\text { glycoprotein (S) of SARS- } \\
\text { CoV-2 [39]. }\end{array}$ & $\begin{array}{l}\text { - Lipids (SM-102,1,2-dimyristoyl-rac-glycero3-methoxy polyethylene } \\
\text { glycol-2000 [PEG2000-DMG], cholesterol and 1,2-distearoyl-snglycero-3- } \\
\text { phosphocholine [DSPC]) } \\
\text { - Tromethamine } \\
\text { - Tromethamine hydrochloride } \\
\text { - } \text { Acetic acid } \\
\text { - Sodium acetate } \\
\text { - Sucrose [39]. }\end{array}$ \\
\hline & $\begin{array}{l}\text { BNT162b2 } \\
\text { (Pfizer) }\end{array}$ & $\begin{array}{l}\text { a highly purified mRNA } \\
\text { encodes the viral spike } \\
\text { from SARS-CoV-2 [40]. }\end{array}$ & $\begin{array}{l}\text { - ALC-0315 } \\
\text { - } \text { ALC-0159 (polyethylene glycol) } \\
\text { - Potassium chloride } \\
\text { - } \text { Potassium dihydrogen phosphate } \\
\text { - } \text { Sodium chloride } \\
\text { - } \text { sucrodium hydrogen phosphate dihydrate } \\
\text { - } \text { water for injection }[40] .\end{array}$ \\
\hline $\begin{array}{l}\text { Adenovirus } \\
\text { Vector Vaccine }\end{array}$ & ChAdOx1-S & $\begin{array}{l}\text { Non-replicating viral } \\
\text { vector, ChAdOx1-S } \\
\text { recombinant } 5 \mathrm{x} \\
10[10] \text { viral particles [41]. }\end{array}$ & $\begin{array}{l}\text { - } \text { Disodium edetate dihydrate (EDTA) } \\
\text { - } \text { ethanol } \\
\text { - L-Histidine } \\
\text { - } \text { Lagnistidine hydrochloride monohydrate } \\
\text { - } \text { Polysorbate } 80 \\
\text { - Sodium chloride } \\
\text { - } \text { Sucrose } \\
\end{array}$ \\
\hline
\end{tabular}

\section{Comparison of each vaccine for covid-19}

\section{- Administration}

Moderna was administered intramuscularly at $100 \mathrm{mcg}$ of mRNA, two doses at 28-day intervals [42]. Pfizer was administered intramuscularly as well as $30 \mathrm{mcg}$ of mRNA, two doses at $21 \mathrm{~d}$ intervals [42]. AstraZeneca vaccine is administered intramuscularly, two doses with the second dose given 4-12 $\mathrm{w}$ after the first dose [41].

\section{- Effectiveness}

Moderna (mRNA-1273): Article states that in phase 3 trials, moderna vaccines showed $94.1 \%$ effectiveness in 99 centers in the United States. Its effectiveness was measured in a 1:1 ratio of vaccine or placebo with 30,420 volunteers. In placebo, there were found symptomatic Covid-19 in 185 volunteers and in the vaccine, 11 participants had symptomatic COVID-19 [36] and it was estimated that for the age category $>=65 \mathrm{y}$ the efficacy was $86.4 \%$ [43].

Pfizer (BNT162b2): Another article explained that the effectiveness of the Pfizer vaccine was tested on 43,548 volunteers in a 1:1 ratio of vaccine or placebo, with the result that 8 volunteers given this vaccine contracted Covid-19 and 162 volunteers who were given a placebo contracted COVID-19, so this Pfizer vaccine has efficacy. in preventing Covid-19 by $95 \%[17,44]$.

AstraZeneca (ChAdOx1[recombinant]): A single dose of this vaccine is estimated to be $80 \%$ efficacy in preventing hospital admission and about $85 \%$ effective in preventing death. Efficacy was also $75 \%$ at age $70 \mathrm{y}$ with the first dose (after $35 \mathrm{~d}$ ) and the initial phase 3 trial demonstrated $70 \%$ efficacy at two doses against symptomatic disease (all ages) [45].

\section{- Safety}

Moderna (mRNA-1273): The safety profile shows a profitable profile. Reactogenicity often ranges in severity from mild to moderate. Reactogenicity and side effects are generally milder and less common in people $>65 \mathrm{y}$ of age. Side effects at the second dose were more frequent and severe than those at the first dose, with an estimated percentage of $0,2-9,7 \%$ [39]. 
Pfizer (BNT162b2): Data from participants aged $>16$ y as many as 37,586 people showed a favorable safety profile. Reactogenicity and side effects are shown with mild severity and rarely occur at age $>55$ y (more in 18-55 y). Side effects at the second dose were more frequent and severe than those at the first dose, with an estimated percentage of $0-4.6 \%$ [40]. The safety profile of this vaccine is mild to moderate; there is generally headache, fatigue, and pain at the injection site. Serious side effects from this vaccine are categorized as low and between vaccine and placebo are the same [17].

AstraZeneca (ChAdOx1[recombinant]): Adverse reactions may occur at the same time (e. g. malaise, myalgia, chills, headache, and fever). Side effects at the first dose were more frequent than in the second dose. And this reaction is generally milder and less common at age $>65$ y [41].

\section{- Side effect}

Moderna (mRNA-1273): The side effects that are felt are mild to moderate in severity. Side effects are dose-dependent and generally occur after the 2 nd vaccination. The following are the most common side effects that are pain at the injection site, headache, fatigue, myalgia, and chills [46].

Pfizer (BNT162b2): Side effects include pain at the injection site as well as swelling and fever, fever, headache, nausea, joint pain, malaise, fatigue, lymphadenopathy. There are also severe allergic reactions and hypersensitivity, vomiting, arm pain, diarrhea [47].

AstraZeneca (ChAdOx1[recombinant]): Very common side effect are pain, tenderness, warmth at the injection site, fatigue, chills (common after second dose), headache, muscle pain, nausea (common after second dose), joint pain, fever/feverishness. Common: localized redness, swelling, and pruritus, induration vomiting (uncommon after the second dose), Uncommon: enlarged lymph nodes. Rare cases are serious thrombosis (blood clots) and thrombocytopenia (low platelets) [48].

\section{- Contraindications}

Moderna (mRNA-1273) and Pfizer (BNT162b2): Moderna and pfizer are contraindicated with a person who is hypersensitive to any component of the vaccine formulation (active ingredient, non-drug ingredient, or component of the container $[39,40]$. In addition to the components of the vaccine, severe allergy contraindications after the previous dose, for example, anaphylaxis [44].

AstraZeneca (ChAdOx1[recombinant]): It is contraindicated in a person who is hypersensitive to a component in the vaccine formulation (active ingredient, non-drug ingredient, or container, as well as a person with thrombocytopenia and a person with venous/arterial thrombosis [48].

\section{- Cost}

The Pfizer vaccine is estimated at \$14.34 per dose. The Moderna vaccine is estimated at $\$ 11.3-18.39$ per dose. The AstraZeneca vaccine is cheaper than others, estimated at \$1.47-2.94 per dose [49]. Another article states that the price of the AstraZenca vaccine ranges from \$2-3 per dose [50]. If converted to rupiah (with a value of $1 \$=14,268.6$ rupiah), then moderna is Rp204,611,724; Pfizer Rp161,235.18-262,399,554; and AstraZeneca Rp20,974,842-41,949,684).

In another article, cost of vaccine are Moderna $\$ 82$, Pfizer $\$ 48$, and AstraZeneca $\$ 30$ for two doses [38]. If converted to rupiah (with a value of $1 \$=14,268.6$ rupiah), then moderna is $\mathrm{Rp} 1,170,025.2$; Pfizer Rp 684,892.8; and AstraZeneca Rp 428,058.

In the future, the successful development of a Covid-19 vaccine must study the previous vaccines made, be able to study their shortcomings and develop for the manufacture of the next vaccine. We hope that there will be a vaccine that actually prevents humans from this Covid-19 virus.

\section{CONCLUSION}

Some vaccines have their own advantages and disadvantages. When viewed from several aspects, such as administration which has different doses. Then seen from the effectiveness of the three vaccines have a sufficient value because they are above $80 \%$. For safety, it has passed clinical trials in humans, but there are still shortcomings in each vaccine of course. The biggest side effect is in Moderna vaccine because it is mild to moderate in severity. Moderna and Pfizer have the same contraindications. For the price of the three vaccines, the most expensive is the Moderna vaccine.

\section{FUNDING}

Nil

\section{AUTHORS CONTRIBUTIONS}

All the authors have contributed equally.

\section{CONFLICT OF INTERESTS}

\section{Declared none}

\section{REFERENCES}

1. Shereen MA, Khan S, Kazmi A, Bashir N, Siddique R. COVID-19 infection: origin, transmission, and characteristics of human coronaviruses. J Adv Res. 2020;24:91-8. doi: 10.1016/j.jare.2020.03.005, PMID 32257431.

2. Kwok KO, Li KK, Wei WI, Tang A, Wong SYS, Lee SS. Editor's Choice: Influenza vaccine uptake, COVID-19 vaccination intention and vaccine hesitancy among nurses: a survey. Int J Nurs Stud. 2021;114:103854. doi: 10.1016/j.ijnurstu.2020.103854, PMID 33326864.

3. Fauci AS, Lane HC, Redfield RR. Covid-19- navigating the uncharted. N Engl J Med. 2020;382(13):1268-9. doi: 10.1056/NEJMe2002387, PMID 32109011.

2. Shereen MA, Khan S, Kazmi A, Bashir N, Siddique R. COVID-19 infection: origin, transmission, and characteristics of human coronaviruses. J Adv Res. 2020;24:91-8. doi: 10.1016/j.jare.2020.03.005, PMID 32257431.

3. Haque A, Pant AB. Efforts at COVID-19 vaccine development: challenges and successes. Vaccines. 2020;8(4):1-16. doi: 10.3390/vaccines8040739, PMID 33291245.

4. Jeyanathan M, Afkhami S, Smaill F, Miller MS, Lichty BD, Xing Z. Immunological considerations for COVID-19 vaccine strategies. Nat Rev Immunol. 2020;20(10):615-32. doi: 10.1038/s41577020-00434-6, PMID 32887954.

5. Calina D, Docea AO, Petrakis D, Egorov AM, Ishmukhametov AA, Gabibov AG, Shtilman MI, Kostoff R, Carvalho F, Vinceti M, Spandidos DA, Tsatsakis A. Towards effective COVID-19 vaccines: updates, perspectives and challenges. Int J Mol Med. 2020;46(1):316. doi: 10.3892/ijmm.2020.4596, PMID 32377694.

6. Malik JA, Mulla AH, Farooqi T, Pottoo FH, Anwar S, Rengasamy KRR. Targets and strategies for vaccine development against SARS-CoV-2. Biomed Pharmacother. 2021;137:111254. doi: 10.1016/j.biopha.2021.111254.

7. Acuna Zegarra MA, Diaz Infante S, Baca Carrasco D. COVID-19 optimal vaccination policies: A modeling study on efficacy, natural and vaccine-induced immunity responses. Math Biosci. 2021;337. PMID 108614.

8. Wibawa T. COVID-19 vaccine research and development: ethical issues. Trop Med Int Health. 2021;26(1):14-9. doi: 10.1111/tmi.13503, PMID 33012020.

9. Dhama K, Sharun K, Tiwari R, Dadar M, Malik YS, Singh KP, Chaicumpa W. COVID-19, an emerging coronavirus infection: advances and prospects in designing and developing vaccines, immunotherapeutics, and therapeutics. Hum Vaccin $\begin{array}{ll}\text { Immunother. } & \text { 2020;16(6):1232-8. }\end{array}$ $10.1080 / 21645515.2020 .1735227$, PMID 32186952.

10. Kostoff RN, Briggs MB, Porter AL, Spandidos DA, Tsatsakis A. [Comment] COVID-19 vaccine safety. Int J Mol Med. 2020;46(5):1599-602. doi: 10.3892/ijmm.2020.4733, PMID 33000193.

11. Lee N, McGeer A. The starting line for COVID-19 vaccine development. Lancet. 2020;395(10240):1815-6. doi: 10.1016/S0140-6736(20)31239-3, PMID 32473680.

12. $\mathrm{Wu}$ SC. Progress and concept for COVID-19 vaccine development. Biotechnol J. 2020;15(6):e2000147. doi: 10.1002/biot.202000147, PMID 32304139.

13. Loomba S, de Figueiredo A, Piatek SJ, de Graaf K, Larson HJ. Measuring the impact of COVID-19 vaccine misinformation on 
vaccination intent in the UK and USA. Nat Hum Behav. 2021;5(3):337-48. doi: 10.1038/s41562-021-01056-1, PMID 33547453.

14. Graham BS. Rapid COVID-19 vaccine development. Science. 2020;368(6494):945-6. doi: 10.1126/science.abb8923.

15. Polack FP, Thomas SJ, Kitchin N, Absalon J, Gurtman A, Lockhart S, Perez JL, Perez Marc G, Moreira ED, Zerbini C, Bailey R, Swanson KA, Roychoudhury S, Koury K, Li P, Kalina WV, Cooper D, Frenck RW, Hammitt LL, Türeci O, Nell H, Schaefer A, Unal S, Tresnan DB, Mather S, Dormitzer PR, Sahin U, Jansen KU, Gruber WC, C4591001 Clinical Trial Group. Safety and efficacy of the BNT162b2 mRNA Covid-19 vaccine. N Engl ] Med. 2020;383(27):2603-15. doi: 10.1056/NEJMoa2034577, PMID 33301246.

16. Chung JY, Thone MN, Kwon YJ. COVID-19 vaccines: the status and perspectives in delivery points of view. Adv Drug Deliv Rev. 2021;170:1-25. doi: 10.1016/j.addr.2020.12.011, PMID 33359141.

17. Gupta T, Gupta SK. Potential adjuvants for the development of a SARS-CoV-2 vaccine based on experimental results from similar coronaviruses. Int Immunopharmacol. 2020;86:106717. doi: 10.1016/j.intimp.2020.106717, PMID 32585611.

18. Rayman MP, Calder PC. Optimizing COVID-19 vaccine efficacy by ensuring nutritional adequacy. Br J Nutr. 2021;50:1-2. doi: 10.1017/S0007114521000386, PMID 33504378.

19. Scialo F, Vitale M, Daniele A, Nigro E, Perrotta F, Gelzo M, Ladev IC. SARS-CoV-2: one year in the pandemic. What have we learned, the new vaccine era and the threat of SARS-CoV-2 variants 2021

20. Fontanet A, Autran B, Lina B, Kieny MP, Karim SSA, Sridhar D. SARS-CoV-2 variants and ending the COVID-19 pandemic Lancet. 2021;397(10278):952-4. doi: 10.1016/S01406736(21)00370-6, PMID 33581803.

21. Mullard A. COVID-19 vaccine development pipeline gears up. Lancet. 2020;395(10239):1751-2. doi: 10.1016/S0140 6736(20)31252-6, PMID 32505245.

22. Oliver SE, Gargano JW, Scobie H, Wallace M, Hadler SC, Leung J, Blain AE, McClung N, Campos-Outcalt D, Morgan RL, Mbaeyi S, MacNeil J, Romero JR, Talbot HK, Lee GM, Bell BP, Dooling K. The advisory committee on immunization practices' interim recommendation for the use of janssen COVID-19 vaccine- United States, February 2021. MMWR Morb Mortal Wkly Rep. 2021;70(9):329-32. doi: 10.15585/mmwr.mm7009e4. PMID 33661860

23. Plotkin SA. Vaccine development and implementation. Vaccin Fact. 2012;B2012:105.

24. Brune KD, Howarth M. New routes and opportunities for modular construction of particulate vaccines: stick, click, and glue. Front Immunol. 2018;9:1432. doi: 10.3389/fimmu.2018.01432, PMID 29997617.

25. Cohen AA, Gnanapragasam PNP, Lee YE, Hoffman PR, Ou S, Kakutani LM, Keeffe JR, Wu HJ, Howarth M, West AP, Barnes CO, Nussenzweig MC, Bjorkman PJ. Mosaic nanoparticles elicit cross-reactive immune responses to zoonotic coronaviruses in mice. Science. 2021:371(6530):735-41. doi: 10.1126/science.abf6840, PMID 33436524.

26. Zakeri B, Fierer JO, Celik E, Chittock EC, Schwarz Linek U, Moy VT, Howarth M. Peptide tag forming a rapid covalent bond to a protein, through engineering a bacterial adhesin. Proc Natl Acad Sci USA. 2012;109(12):E690-7. doi: 10.1073/pnas.1115485109, PMID 22366317.

27. Izda V, Jeffries MA, Sawalha AH. COVID-19: a review of therapeutic strategies and vaccine candidates. Clin Immunol. 2021;222. doi: 10.1016/j.clim.2020.108634.

28. Lee HJ, Choi JH. Tetanus-diphtheria-acellular pertussis vaccination for adults: an update. Clin Exp Vaccine Res. 2017;6(1):22-30. doi: 10.7774/cevr.2017.6.1.22, PMID 28168170.

29. Sharma O, Sultan AA, Ding H, Triggle CR. A review of the progress and challenges of developing a vaccine for COVID-19. Front Immunol. 2020;11:585354. doi: 10.3389/fimmu. 2020.585354. PMID 33163000.

30. Shahcheraghi SH, Ayatollahi J, Aljabali AA, Shastri MD, Shukla SD, Chellappan DK, Jha NK, Anand K, Katari NK, Mehta M, Satija
S, Dureja H, Mishra V, Almutary AG, Alnuqaydan AM, Charbe N, Prasher P, Gupta G, Dua K, Lotfi M, Bakshi HA, Tambuwala MM. An overview of vaccine development for COVID-19. Ther Deliv. 2021;12(3):235-44. doi: 10.4155/tde-2020-0129, PMID 33624533.

31. Batty CJ, Heise MT, Bachelder EM, Ainslie KM. Vaccine formulations in clinical development for the prevention of severe acute respiratory syndrome coronavirus 2 infection. Adv Drug Deliv Rev. 2021;169:168-89. doi: 10.1016/j.addr.2020.12.006, PMID 33316346.

32. Jackson LA, Anderson EJ, Rouphael NG, Roberts PC, Makhene M, Coler RN, McCullough MP, Chappell JD, Denison MR, Stevens LJ, Pruijssers AJ, McDermott A, Flach B, Doria-Rose NA, Corbett KS, Morabito KM, O'Dell S, Schmidt SD, Swanson PA, Padilla M, Mascola JR, Neuzil KM, Bennett H, Sun W, Peters E, Makowski M, Albert J, Cross K, Buchanan W, Pikaart Tautges R, Ledgerwood JE, Graham BS, Beigel JH, mRNA-1273 Study Group. An mRNA vaccine against SARS-CoV-2- preliminary report. N Engl J Med. 2020;383(20):1920-31. doi: 10.1056/NEJMoa2022483, PMID 32663912.

33. Li Y, Tenchov R, Smoot J, Liu C, Watkins S, Zhou Q. A comprehensive review of the global efforts on COVID-19 vaccine development. ACS Cent Sci. 2021;7(4):512-33. doi: 10.1021/acscentsci.1c00120, PMID 34056083

34. Baden LR, El Sahly HM, Essink B, Kotloff K, Frey S, Novak R, Diemert D, Spector SA, Rouphael N, Creech CB, McGettigan J, Khetan S, Segall N, Solis J, Brosz A, Fierro C, Schwartz H, Neuzil K, Corey L, Gilbert P, Janes H, Follmann D, Marovich M, Mascola J, Polakowski L, Ledgerwood J, Graham BS, Bennett H, Pajon R, Knightly C, Leav B, Deng W, Zhou H, Han S, Ivarsson M, Miller J, Zaks T, COVE Study Group. Efficacy and safety of the mRNA1273 SARS-CoV-2 vaccine. N Engl J Med. 2021;384(5):403-16. doi: 10.1056/NEJMoa2035389, PMID 33378609.

35. Kaur SP, Gupta V. Since January 2020 Elsevier has created a COVID-19 resource centre with free information in English and Mandarin on the novel coronavirus COVID-19. The COVID-19 resource centre is hosted on Elsevier Connect, the company's public news and information; 2020.

36. Yang S, Hua M, Liu X, Du C, Pu L, Xiang P, Wang L, Liu J. Bacterial and fungal co-infections among COVID-19 patients in the intensive care unit. Microbes Infect. 2021;23(4-5):104806. doi: 10.1016/j.micinf.2021.104806, PMID 33684520.

37. WHO. Background document on the mRNA-1273 vaccine. Who; 2021. p. 2

38. WHO. Background document on the mRNA vaccine BNT162b2 (Pfizer-BioNTech) against COVID-19. Who. 2021;2:1-44.

39. Vaccine AC. Astra Zeneca COVID-19 vaccine product monograph. Vol. 1. ASTRAZENECA CANADA INC; 2021. p. 1-23.

40. Verbeke R, Lentacker I, De Smedt SC, Dewitte H. Since January 2020 Elsevier has created a COVID-19 resource centre with free information in English and Mandarin on the novel coronavirus COVID-19. The COVID-19 resource centreis hosted on Elsevier Connect, the company's public news and information; 2020.

41. Antonelli Incalzi RI, Trevisan C, Del Signore S, Volpato S, Fumagalli S, Monzani F, Bellelli G, Gareri P, Mossello E, Malara A, Coin A, Zia G, Ranhoff AH. Are vaccines against COVID-19 tailored to the most vulnerable people? Vaccine. 2021;39(17):2325-7. doi: 10.1016/j.vaccine.2021.03.066, PMID 33810907.

42. Schoenmaker L, Witzigmann D, Kulkarni JA, Verbeke R. Since January 2020 Elsevier has created a COVID-19 resource centre with free information in English and Mandarin on the novel coronavirus COVID-19. The COVID-19 resource centre is hosted on Elsevier Connect, the company's public news and information; 2020.

43. Bernal J, Andrews N, Gower C, Robertson C, Stowe J, Tessier E, Simmons R. Effectiveness of the Pfizer-BioNTech and OxfordAstra Zeneca vaccines on covid-19 related symptoms, hospital admissions, and mortality in older adults in England: test negative case-control study. Br Med J. 2021;373.

44. Anderson EJ, Rouphael NG, Widge AT, Jackson LA, Roberts PC, Makhene M, Chappell JD, Denison MR, Stevens LJ, Pruijssers AJ, McDermott AB, Flach B, Lin BC, Doria-Rose NA, O'Dell S, Schmidt SD, Corbett KS, Swanson PA, Padilla M, Neuzil KM, 
Bennett H, Leav B, Makowski M, Albert J, Cross K, Edara VV, Floyd K, Suthar MS, Martinez DR, Baric R, Buchanan W, Luke CJ Phadke VK, Rostad CA, Ledgerwood JE, Graham BS, Beigel JH, mRNA-1273 Study Group. Safety and immunogenicity of SARSCoV-2 mRNA-1273 vaccine in Oolder Aadults. N Engl J Med. 2020;383(25):2427-38. doi: 10.1056/NEJMoa2028436, PMID 32991794.

45. Middleton E. Fact sheet for healthcare providers administering vaccine (vaccination providers); 2019. p. 1-37.
46. Health M. Administration of Astra Zeneca COVID19/COVISHIELD vaccine. Covishield. 2021:1-13.

47. Putter JS. Since January 2020 Elsevier has created a COVID-19 resource centre with free information in English and Mandarin on the novel coronavirus COVID-19. The COVID-19 resource centre is hosted on Elsevier Connect, the company' s public news and information; 2020.

48. Knoll MD, Wonodi C. Oxford-Astra Zeneca COVID-19 vaccine efficacy. Lancet. 2021;397(10269):72-4. doi: 10.1016/S01406736(20)32623-4. PMID 33306990. 